P. Colombani

S. Späti

C. Spleiss

P. Frey-Rindova

C. Wenk

\section{Exercise-induced sweat nitrogen excretion: evaluation of a regional collection method using gauze pads}

Belastungsbedingte Stickstoffverluste über den Schweiss: Auswertung einer lokalen Sammelmethode mit Gazen

Summary The exercise-induced sweat nitrogen excretion was investigated during a 45-minute run at moderate intensity on a treadmill. Sweat was collected with a regional collection technique using gauze pads and compared with the whole-body wash-down (WBW) method. In the regional collection, sweat was sampled from the upper back (UB), lower back (LB), abdomen (AB), and thigh (TH). Additionally, the relation of sweat urea, ammonia, and amino acids was investigated with the regional collection method during a second 45-minute run. Independent of the sweat collection method, a significant and positive correlation

Received: 22 January 1997

Accepted: 4 July 1997

Dipl. Lm.-Ing. P. Colombani (®) · S. Späti

C. Spleiss - P. Frey-Rindova - C. Wenk

INW Nutrition Biology

ETH Zentrum, LFW A33

CH-8092 Zurich, Switzerland

E-mail: paolo.colombani@inw.agrl.ethz.ch was found between sweat rate and the excretion rate of the largest nitrogen fraction urea, suggesting that the sweating response to exercise might be one of the most important factors determining absolute sweat nitrogen losses. The urea nitrogen excretion was nearly $140 \mathrm{mg} \cdot \mathrm{h}^{-1}$ in the second run, representing the largest nitrogen fraction. Ammonia nitrogen and amino acid-derived nitrogen rate were approximately $30 \mathrm{mg} \cdot \mathrm{h}^{-1}$ and $10 \mathrm{mg} \cdot \mathrm{h}^{-1}$, respectively. The comparison of the sampling methods during the first run revealed that the urea nitrogen rate was significantly higher, but the ammonia nitrogen rate significantly lower in the WBW. After summing urea and ammonia nitrogen, no significant difference between the methods was observed anymore, except for UB. It is concluded that the regional collection method using gauze pads is a valuable approach to measure exercise-induced sweat nitrogen losses during moderate running exercise.

Zusammenfassung Die belastungsbedingte Ausscheidung von Stickstoff über den Schweiss wurde während eines mit moderater Intensität durchgeführten 45-Minuten-Laufes auf einem Laufband bestimmt. Schweissproben wurden mittels einer lokalen Sammelmethode mit Ga- zen und zum Vergleich mit dem Ganzkörper-Waschverfahren entnommen. In der lokalen Methode wurde der Schweiss vom oberen und unteren Rücken, Bauch und Oberschenkel gesammelt. Während eines zweiten 45-Minuten-Laufes wurde zusätzlich das Verhältnis von Harnstoff, Ammoniak und Aminosäuren im Schweiss analysiert. Es konnte eine von der Sammelmethode unabhängige, signifikant positive Korrelation zwischen Schweissrate und Ausscheidungsrate der grössten Stickstoffraktion im Schweiss (Harnstoff) beobachtet werden. Dies lässt den Schluss zu, dass die Schweissrate einer der wesentlichen Faktoren ist, der die Stickstoffverluste im Schweiss festlegt. Die Ausscheidungsrate des Harnstoffstickstoffes betrug im zweiten Lauf etwa $140 \mathrm{mg} \cdot \mathrm{h}^{-1}$, die des Ammoniakstickstoffes etwa 30 $\mathrm{mg} \cdot \mathrm{h}^{-1}$ und die des Aminosäurenstickstoffes rund $10 \mathrm{mg} \cdot \mathrm{h}^{-1}$. Der Vergleich beider Sammelmethoden während des ersten Laufes zeigte, dass die Ausscheidungsrate des Harnstoffstickstoffes im GanzkörperWaschverfahren signifikant höher, die des Ammoniakstickstoffes dagegen signifikant niedriger war. Dieser Unterschied zwischen den Methoden verschwand, nachdem Harnstoff- und Ammoniakstickstoff summiert wurden, ausser für den oberen Rücken. Die Bestimmung von belastungsbedingten Stickstoffverlusten über den Schweiss mit- 
tels der lokalen Sammelmethode kann für mit moderater Intensität durchgeführten Läufe empfohlen werden.
Key words Aerobic exercise sweat nitrogen losses - whole-body washdown - regional sweat collection
Schlüsselwörter Aerobe körperliche Belastung - Schweiss-Stickstoffverluste - Ganzkörper-Waschverfahren - lokale SchweissSammelmethode

\section{Introduction}

Optimizing sports performance is a major goal of physically active people and proper nutrition can help to achieve this goal. The most important nutritional aspects to optimize sports performance are to maintain energy, fluid, and nitrogen balance over an extended period of time. The analysis of the nitrogen balance in sedentary people involves quantitative analysis of dietary nitrogen intake and urinary and fecal nitrogen excretion. In exercising people, nitrogen balance analysis must also focus on the sweat nitrogen excretion, since some authors provided evidence for substantial sweat nitrogen losses during exercise $\left(100-400 \mathrm{mg} \cdot \mathrm{h}^{-1}\right)(6,17)$. An appropriate method for collecting sweat samples for nitrogen analysis must therefore be used. Previously, sweat samples were either collected by the whole-body washdown (WBW) or by much easier applicable regional collection methods $(5,9,17,18)$. In the WBW, subjects and exercise clothing are rinsed after exercising and the wash water of body and clothes is subsequently analyzed. In the regional collection method, sweat is sampled with small gauze pads or capsules that are fixed on the skin and whole-body losses are extrapolated from regional losses.

Most studies analyzing nitrogenous sweat compounds have used the regional collection method $(3,5,9,10$, $16,17,20)$; however, the WBW method is claimed to be the criterion measure (17). While the regional collection method tends to give higher sweat urea (17) and total nitrogen excretion values (8) than the WBW, the absolute difference between the methods is quite small at low to moderate exercise intensities.

According to our knowledge, there is only one study reporting amino acid sweat losses during exercise (20). The results of that work suggest that the amino acid-derived nitrogen losses $\left(\sim 200 \mathrm{mg} \cdot \mathrm{L}^{-1}\right)$ are as high as urea nitrogen losses when sweat is collected from the forearm. However, the reported value probably overestimates the effective loss, because different sweat nitrogen compounds yield much higher values when measured from the arms as compared to the trunk $(8,14,15)$.

We decided to evaluate the feasibility of a regional sweat collection method using gauze pads for the use in field tests by comparing it with the WBW. Additionally, we also planned to verify the high sweat amino acid losses that were reported previously (20).

\section{Materials and methods}

A 45 -minute $\left(45^{\prime}\right)$ run at moderate intensity was chosen as the test model, as this is a common exercise practise. The run was performed on a motor-driven treadmill where sweat was sampled both with regional collection and WBW (Run 1). Since the amino acid loss could not be analyzed in this run because the sampled sweat volume was not sufficient, a second $45^{\prime}$ run (Run 2) was performed at a later time. Sweat was collected only with regional collection in Run 2, because preliminary analyses revealed that in the wash water of the WBW the concentrations of most amino acids would have been below the reliable concentration of the analytical system.

\section{Subjects}

Nineteen healthy and moderately- to well-trained men volunteered and agreed to participate in this study after being informed about its purpose and possible risks. Ten subjects participated in Run 1 and nine in Run 2 . The characteristics of the athletes are described in Table 1. Each subject's anaerobic threshold was determined according to Simon et al. (21) on a motor-driven treadmill ( $1.5 \%$ grade) the week before the $45^{\prime}$ run. The athletes were advised to refrain from any intense physical activity the day before the determination of the anaerobic threshold, as well as before the $45^{\prime}$ run (see next paragraph). Additionally, carbohydrate-rich meals were prescribed qualitatively on the day before both occasions. The athletes reported to the laboratory during the morning of the test days after having consumed a qualitatively prescribed carbohydrate-rich breakfast. Physical activity and food intake were recorded on a protocol.

\section{5-Minute run}

Nude body weight was recorded with a precision of $50 \mathrm{~g}$ before and after the run to calculate sweat loss. Both $45^{\prime}$ runs were performed on a motor-driven treadmill $(1.5 \%$ grade) at an intensity that corresponded to about $75 \%$ of the speed at each individual's anaerobic threshold. Room temperature and degree of humidity during Run 1 and Run 2 were approximately $18{ }^{\circ} \mathrm{C}$ and $40 \%$, and $20^{\circ} \mathrm{C}$ and $50 \%$, respectively. No fluid or food intake was allowed during the run. Sweat dropping from the face was collected with a small towel and considered together with the exercise clothing in the WBW analysis. 
Sweat nitrogen losses during exercise

Table 1 Characteristics of the subjects (median and interquartile range)

\begin{tabular}{lccccc}
\hline Trial & Subjects & Age (years) & Weight $(\mathrm{kg})$ & Running exercise $\left(\mathrm{h} \cdot \mathrm{wk}^{-1}\right)$ & Other exercise $\left(\mathrm{h} \cdot \mathrm{wk}^{-1}\right)$ \\
Run 1 & 10 & $25(22-26)$ & $70(65-72)$ & $3.0(0.0-3.8)$ & $7.5(4.0-11.0)$ \\
Run 2 & 9 & $25(21-28)$ & $66(62-70)$ & $1.0(0.0-1.5)$ & $4.0(0.5-5.3)$ \\
\hline
\end{tabular}

\section{Regional sweat collection}

Sweat was collected using gauze pads which were fixed on the upper back (UB) and lower back (LB). Additional gauze pads were also placed on the abdomen $(A B)$ and thigh (TH) in Run 1 . The sterilized pads $(6 \times 8 \mathrm{~cm}, 100 \%$ cotton) were placed symmetrically on the right and left part of each body part with a dressing (Ensure-it ${ }^{\mathrm{TM}}, 12.7$ $x 17.5 \mathrm{~cm}$, Becton Dickinson Vascular Access, Utah, USA) that was fixed subsequently with an adhesive plaster. The skin was disinfected with pure isopropanol before placing the gauze pads on the body to avoid possible microorganism activity. The gauze pads were removed after the run, placed into a tared syringe and weighed. Syringes were then used to squeeze the sweat out of the gauze pads. Sweat was analyzed immediately for urea and ammonia, whereas a sweat aliquot was stored at $-70{ }^{\circ} \mathrm{C}$ for amino acid analysis (only Run 2 ).

Whole-body washdown

The subjects of Run 1 took a pre-experimental shower to remove possible traces of urea, ammonia, or amino acids from the skin. Thereafter, the gauze pads for the regional sweat collection were fixed to the skin and the athletes were dressed with underwear, socks, long tights, and long-sleeved shirts that were previously washed with deionized water.

The exercise clothing was collected after the run and rinsed in deionized water. Meanwhile, the athletes took a post-experimental shower for two minutes in a shower with closed water circulation ( $2.5 \mathrm{~L}$ deionized water). The shower water and laundry water were analyzed immediately for urea and ammonia.

\section{Biochemical analysis}

All materials used for sweat sampling did not contain detectable amounts of urea and only negligible traces of ammonia. Urea and ammonia were analyzed enzymatically at $37^{\circ} \mathrm{C}$ on a Cobas-Mira analyzer (Hoffmann-La Roche, Basel, Switzerland) using commercially available assay kits. An urease-glutamate dehydrogenase kit was used for urea (Hoffmann-La Roche, Basel, Switzerland) and a glutamate dehydrogenase kit for ammonia (Boehringer Mannheim GmbH, Mannheim, Germany). Since the urea analysis does not distinguish between urea and ammonia, urea values were corrected by subtracting am- monia values (two mol ammonia correspond with one mol urea). Free amino acids were analyzed by high performance liquid chromatography (LKB 4151 Alpha Plus, Pharmacia LKB, Bromma, Sweden) after having filtered the sweat sample through a $0.2 \mu \mathrm{m}$ filter membrane. Amino acids having a concentration below the reliable detection limit of the assay system $\left(\leq 10 \mu \mathrm{mol} \cdot \mathrm{L}^{-1}\right)$ were included in the calculation of the amino acid-derived nitrogen loss using a concentration of $10 \mu \mathrm{mol} \cdot \mathrm{L}^{-1}$. The analyzed free amino acids were alanine, arginine, aspargine, aspartic acid, cysteine, glutamine, glutamic acid, glycine, histidine, isoleucine, leucine, lysine, methionine, ornithine, phenylalanine, serine, taurine, threonine, tyrosine, and valine.

\section{Sweat loss}

Total sweat loss during the run was calculated as the difference between the nude body weight before and after the run minus estimated respiratory and metabolic losses of $125 \mathrm{~g}$.

Calculation of urea, ammonia, and amino acid sweat loss

In the regional collection method, whole-body urea, ammonia, and amino acid losses were calculated by extrapolation of the local losses. The concentration of each gauze was multiplied by total sweat loss and the respective molecular mass. WBW losses were calculated by multiplying the concentration in the laundry and shower water with the amount of water that was used and the respective molecular mass. Then, the content of the respective component of the gauze pads was added to the values of laundry and shower water. Total nitrogen loss was calculated by adding up the nitrogen portion of each analyzed component.

\section{Statistical analysis}

All statistical analyses were performed with the STATISTICA/W ${ }^{\mathrm{TM}}$ software version 4.5 (Statsoft $^{\mathrm{TM}}$ Inc., Tulsa OK, USA). Mann-Whitney U-Test was performed to detect differences between Run 1 and Run 2, and Wilcoxon matched pairs test was used when comparing paired samples within a run. In addition, Spearman's $R$ was calculated to look for correlations. The level of significance was set at $p \leq 0.05$. Data in tables and text are presented as median and interquartile range. 


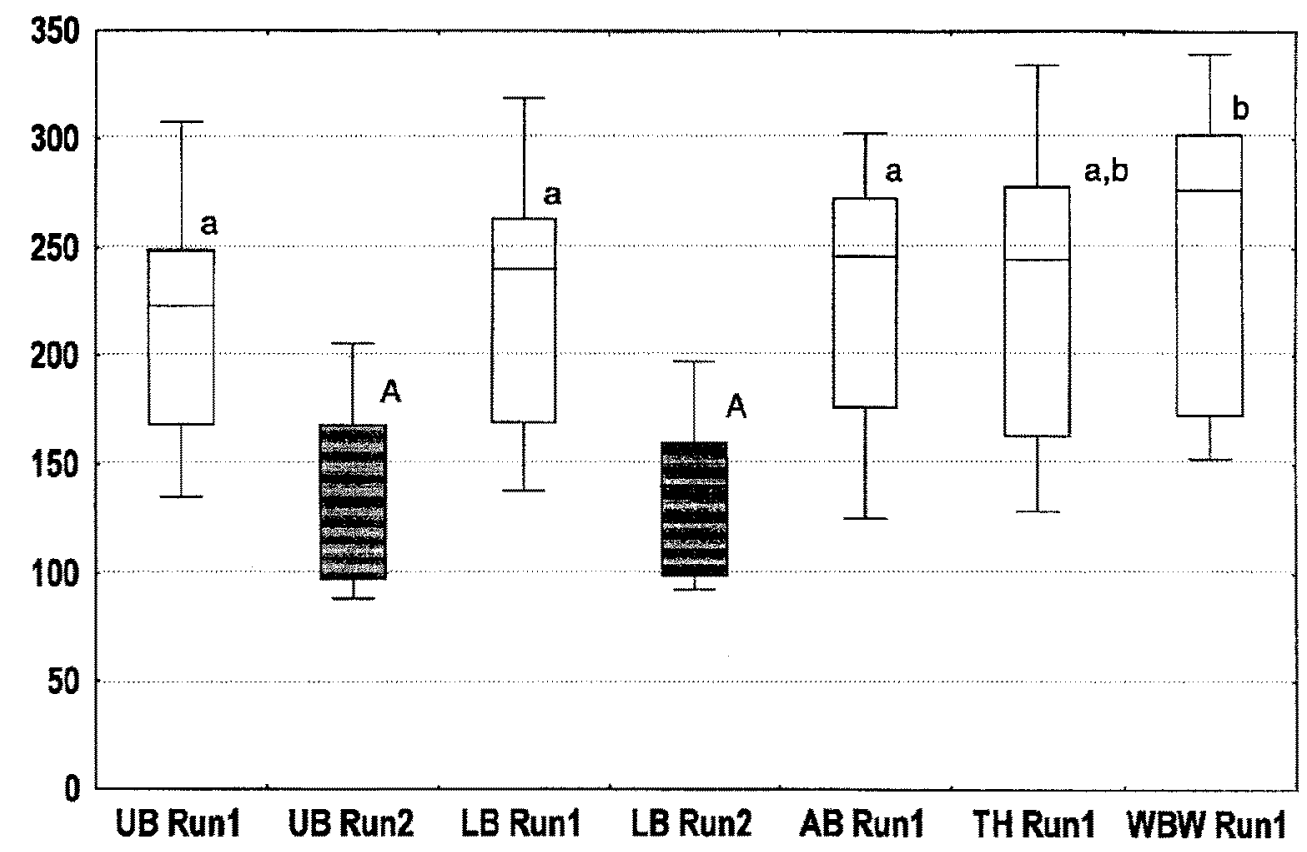

Fig. 1 Urea nitrogen sweat excretion in $\mathrm{mg} \cdot \mathrm{h}^{-1}(\mathrm{UB}=$ upper back, $\mathrm{LB}=$ lower back, $\mathrm{AB}=$ abdomen, $\mathrm{TH}=$ thigh, $\mathrm{WBW}=$ whole-body washdown). Results of Run 1 are presented as white boxplots and those of Run 2 as gray boxplots. The boxplots divide the data into four areas of equal frequency. The central box covers the middle $50 \%$ of the values between the lower and upper quartile, while the horizontal line inside the box is the median. The vertical lines outside the box extend to data points within 1.5 interquartile range. Separate data points are outliers (between 1.5 and 3.0 interquartile range). Box plots sharing a common regular letter are not statistically different $(p>0.05)$ in Run 1 , boxplots sharing a common capital letter are not statistically different $(p>0.05)$ in Run 2.

\section{Results}

The amount of weekly exercise differed to some extent between the subjects of Run 1 and Run 2, but the differences failed to reach significance $(p>0.06)$. On the other hand, the blood lactate concentration at each individual's anaerobic threshold was significantly lower in the subjects of Run $1(\mathrm{p}<0.05)$. The distance covered during Run 1 and Run 2 was 7.7 (7.4-8.3) km and 8.1 (7.7-8.6) $\mathrm{km}$, respectively, and not statistically different.

In Run 1, the sweat rate was $1.02(0.87-1.13) \mathrm{kg} \cdot \mathrm{h}^{-1}$ and significantly higher than during Run $2 \quad(0.77$ $\left.(0.63-0.83) \mathrm{kg} \cdot \mathrm{h}^{-1}\right)$. Urea nitrogen (urea-N) and ammonia nitrogen (ammonia- $\mathrm{N}$ ) excretion rates were also both significantly higher in Run 1 compared to Run 2.

\section{Nitrogenous sweat components}

In both runs, no significant differences were found between the two gauze pads that were placed symmetrically on the same body part. The average of these two gauze pads was, therefore, used for statistical analyses. Results of urea- $\mathrm{N}$ and ammonia- $\mathrm{N}$ excretion rate are presented in Figs. 1 and 2, respectively.

\section{Regional collection}

No significant differences were found in the urea-N excretion rate between each body part within the respective run (Fig. 1). In contrast, the rate of ammonia- $\mathrm{N}$ excretion was significantly different between all body sites, except for $L B$ versus $A B$ in Run 1 , and $U B$ versus $L B$ in Run 2 (Fig, 2). The correlation analyses revealed that the urea-N excretion rates of all body sites were significantly correlated to each other $(\mathrm{R}=0.73-0.96, \mathrm{p}=0.02-0.001)$ within the respective run as well as the ammonia- $\mathrm{N}$ rates $(\mathrm{R}=0.68-0.92, \mathrm{p}=0.03-0.001$, except for $\mathrm{AB}$ vs $\mathrm{TH}$ : $\mathrm{R}=0.60, \mathrm{p}>0.07)$. Within a body site, urea-N and ammonia- $\mathrm{N}$ were not significantly correlated to each other $(\mathrm{R}=0.56-0.62, \mathrm{p}>0.09)$ except for $\mathrm{TH}(\mathrm{R}=0.90$, $\mathrm{p}<0.001)$. The sweat rate was significantly correlated to the urea- $\mathrm{N}$ rate of all body sites $(\mathrm{R}=0.73-0.89$, $p<0.04)$ except for $L B$ in Run $2(R=0.52, p>0.14)$.

\section{Comparison of nitrogenous sweat fractions}

In Run 2, the rate of urea-N, ammonia- $\mathrm{N}$, and amino acid nitrogen excretion in UB were $134 \mathrm{mg} \cdot \mathrm{h}^{-1}(79 \%), 27$ $\mathrm{mg} \cdot \mathrm{h}^{-1}(16 \%)$, and $9 \mathrm{mg} \cdot \mathrm{h}^{-1}(5 \%)$, respectively. The data for $\mathrm{LB}$ were $140 \mathrm{mg} \cdot \mathrm{h}^{-1}(77 \%), 31 \mathrm{mg} \cdot \mathrm{h}^{-1}(17 \%)$, and $10 \mathrm{mg} \cdot \mathrm{h}^{-1}(6 \%)$, respectively. 
Fig. 2 Ammonia nitrogen sweat excretion in $\mathrm{mg} \cdot \mathrm{h}^{-1}$ (for abbreviations and explanations see Fig. 1).

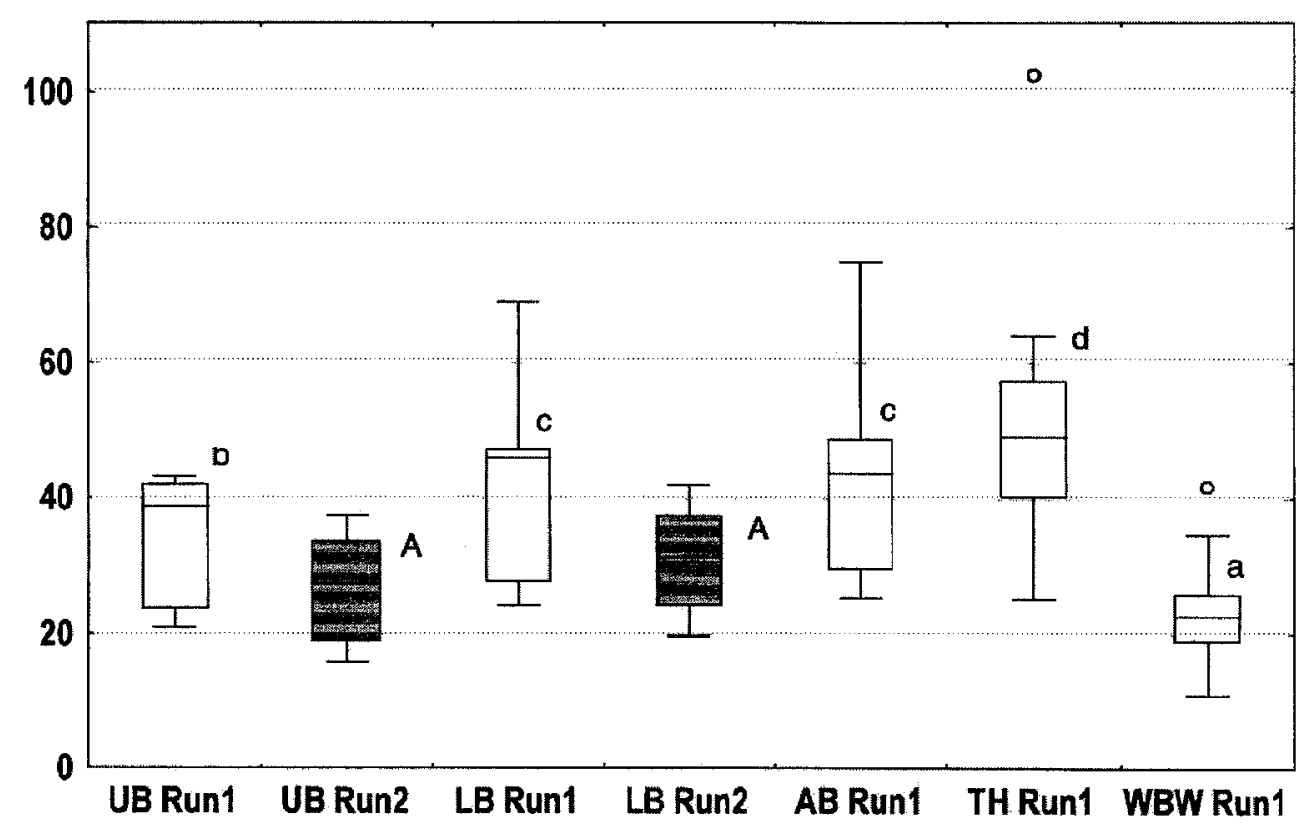

Whole-body washdown

Urea- $\mathrm{N}$ and ammonia- $\mathrm{N}$ excretion rates are shown in Figs. 1 and 2, respectively. The urea- $\mathrm{N}$ excretion rate was highly correlated $(\mathrm{R}=0.94, \mathrm{p}<0.001)$ with the sweat rate.

Comparison between regional collection and whole-body washdown

The urea- $\mathrm{N}$ excretion rate was significantly higher in the WBW compared to all body sites $(\mathrm{p}<0.01)$ except for $\mathrm{TH}$ ( $\mathrm{p}>0.07$, Fig. 1). In contrast, the ammonia-N rate was significantly lower in the WBW compared to all body sites ( $p<0.006$, Fig. 2). After summing urea-N and ammonia- $\mathrm{N}$, no significant difference between the methods was observed ( $p>0.72$ ), except for UB, which was higher in the WBW $(\mathrm{p}<0.04)$.

\section{Discussion}

The main finding in our study is that the difference in sweat nitrogen losses between the regional collection method using gauze pads and the WBW is rather low during moderate running exercise when both urea and ammonia losses are considered.

The urea-N rate of excretion measured by WBW in the present study was significantly higher by 12 to $24 \%$ compared to the regional estimates. In contrast, Lemon et al. (17) showed no difference between the WBW and a regional collection method using small capsules when a 60 minute-long treadmill exercise was performed at intensities of 42 or $55 \% \mathrm{VO}_{2} \max$. At an intensity of $67 \% \mathrm{VO}_{2} \max$, the urea-N rate was even lower in the WBW. An explanation for this discrepancy between the results of both studies is not evident.

The urea- $\mathrm{N}$ rate varied widely during both runs at moderate intensity in our study (Fig. 1). This is in line with previous reports documenting variable urea- $\mathrm{N}$ excretion rates between 100 and $400 \mathrm{mg} \cdot \mathrm{h}^{-1}$ (17) and 320 and $490 \mathrm{mg} \cdot \mathrm{h}^{-1}$ (3). Reasons for a large variation in sweat urea losses include sweat rate (see next paragraph), status of the glycogen stores (16), protein content of the preexercise diet (6), and ambient temperature (11). Furthermore, it has been suggested that acclimatization to heat is an important factor in reducing sweat nitrogen losses (2).

The urea- $\mathrm{N}$ rate in Run 1 was markedly higher than in Run 2 (Fig. 1). This difference can be explained largely by the $25 \%$ lower sweat rate of the subjects in Run 2, since a significant, positive correlation was observed between sweat rate and urea- $\mathrm{N}$ excretion. Two reasons may be responsible for the higher sweat rate in Run 1. The subjects wore long-sleeved shirts and long tights to facilitate sweat sampling for the WBW. The heat transfer by conduction and convection was probably more difficult compared to the subjects of Run 2 who were dressed with T-shirts and shorts. Therefore, heat removal from the skin was probably compensated by increased evaporation (i.e., sweating rate). The second reason for the higher sweat rate might be that the athletes of Run 1 were probably better trained, since their blood lactate concentration was significantly lower at the individual anaerobic threshold. A positive relation between $\mathrm{VO}_{2}$ and 
sweat loss during a 60 minute run was reported (13) and physical training was shown to improve peripheral sweat production (4). The positive correlation between sweat rate and rate of the largest nitrogen fraction urea suggests that the absolute sweat nitrogen loss might at least in part be a function of the sweat rate, although an inverse relation between sweat rate and sweat nitrogen concentration was documented (8).

Urea represented the largest fraction of the three analyzed nitrogenous sweat components. This finding is consistent with results from non-exercising subjects where sweating was induced by heat (1). The relation between sweat urea-N, ammonia- $\mathrm{N}$, and amino acidderived nitrogen in our study was also similar to the one reported by Araki and Ando (1), which was $70 \%$ urea-N and $30 \%$ ammonia- $\mathrm{N}$ and amino acid nitrogen. Ammonia- $\mathrm{N}$ and amino acid nitrogen in our study corresponded approximately $30 \%$ of the urea- $\mathrm{N}$ loss. Their contribution to whole-body nitrogen losses in regularly exercising people should, therefore, not be neglected. The rate of ammonia- $\mathrm{N}$ excretion in our study (Fig. 2) was comparable with other findings $\left(30-45 \mathrm{mg} \cdot \mathrm{h}^{-1} ; 9,10\right)$. Interestingly, the ratio of ammonia- $\mathrm{N}$ to urea- $\mathrm{N}$ in the regional collection method was approximately $1: 4$, regardless of body site and respective excreted amounts. Sweat ammonia concentrations ranging between 1 and $5 \mathrm{mmol} \cdot \mathrm{L}^{-1}$ indicate that sweating might be an important clearance pathway of blood ammonia that is not further metabolized. This is underlined by considering that kidneys do not take up ammonia (12) and that ammonia expiration by the lung during aerobic exercise seems to be negligible (7).

As discussed above, the ammonia-N sweat loss was nearly $20 \%$ of the urea- $\mathrm{N}$ sweat loss in the regional collection method, but only $10 \%$ in the WBW method. This significant difference between the sampling methods was probably due to evaporation of the ammonia in the WBW, which was caused by the "mechanical movement" of shower water and laundry water.
The absolute nitrogen loss deriving from amino acid excretion was lower than the urea or ammonia nitrogen loss. Our results of approximately $10 \mathrm{mg} \cdot \mathrm{h}^{-1}$ could not confirm previous data reported by Liappis et al. (20) who found extremely high amino acid-derived nitrogen losses of approximately $200 \mathrm{mg} \cdot \mathrm{L}^{-1}$ and $400 \mathrm{mg} \cdot \mathrm{L}^{-1}$ sweat in trained and untrained subjects, respectively. This large difference can not be solely explained by the different study designs. In their study, sweat was sampled from the forearm during a very short-lasting exercise (15 $\mathrm{min}$ cycling at $150 \mathrm{~W}$ ). Indeed, earlier findings on heat-provoked amino acid sweat excretion showed that extremities had higher amino acid concentrations than the trunk, but only by a factor of approximately three (15). The amino acid-derived nitrogen levels in sweat from the back in their study were similar to our results $\left(7-16 \mathrm{mg} \cdot \mathrm{L}^{-1}\right.$; 15).

The current daily dietary protein recommendation is $0.8 \mathrm{~g} \cdot \mathrm{kg}^{-1}$ body mass (22). Increased amino acid oxidation and sweat and urinary urea excretion in endurance athletes suggest that the protein requirement for regularly exercising athletes is increased compared to sedentary individuals. Considering this raised need for nitrogen, the daily protein recommendation for endurance athletes is now set to 1.2 to $1.4 \mathrm{~g}$ protein $\cdot \mathrm{kg}^{-1}$ body mass (19).

In summary, the difference between regional sweat collection using gauze pads and WBW in subjects running at a moderate intensity is small in regard of sweat nitrogen losses. The former method can, therefore, be recommended for the analysis of sweat nitrogen in exercising people, especially because it is easier to apply than the WBW in a field test.

Acknowledgments This work was supported by a grant of Nestec Ltd. (Switzerland) to Caspar Wenk.

\section{References}

1. Araki Y, Ando S (1953) Urea, amino acid and ammonia in human sweat. Japan J Physiol 3:211-218

2. Ashworth A, Harrower ADB (1967) Protein requirements in tropical countries: nitrogen losses in sweat and their relation to nitrogen balance. Br J Nutr 21:833-843

3. Brouns F, Saris WHM, Stroecken J, Beckers E, Thijssen R, Rehrer NJ, Hoor $F(1988)$ The effect of diet manipulation and repeated sustained exercise on nitrogen balance, a controlled tour de France simulation study, part 3. In: Brouns $F$ (ed) Food and fluid related aspects in highly trained athletes. Uitgeverij De Vrieseborch, Haarlem, pp 73-81
4. Buono MJ, Sjoholm NT (1988) Effect of physical training on peripheral sweat production. J Appl Physiol 65:811-814

5. Calles-Escandon J, Cunningham JJ, Snyder P, Jacob R, Huszar G, Loke J, Felig $P$ (1984) Influence of exercise on urea, ceratinine and 3-methylhistidine excretion in normal human subjects. Am J Physiol 246:E334-E338

6. Calloway DH, Odell ACF, Margen S (1971) Sweat and miscellaneous nitrogen losses in human balance studies. J Nutr 101:775-786

7. Colombani P, Zehnder M, Wenk C (1996) Ammonia expiration during endurance exercise. Med Sci Sports Exerc 28 (Suppl):S62 (abstract)
8. Costa F, Calloway DH, Margen S (1969) Regional and total body sweat composition of men fed controlled diets. Am J Clin Nutr 22:52-58

9. Czarnowski D, Górski J (1991) Sweat ammonia excretion during submaximal cycling exercise. J Appl Physiol $70: 371-374$

10. Czarnowski D, Langfort J, Pilis W, Górski J (1995) Effect of a low carbohydrate diet on plasma and sweat ammonia concentrations during prolonged nonexhausting exercise. Eur J Appl Physiol 70:70-74

11. Dolny DG, Lemon PW (1988) Effect of ambient temperature on protein breakdown during prolonged exercise. J Appl Physiol 64:550-555 
12. Graham TE, Rush JWE, MacLean DA (1995) Skeletal muscle amino acid metabolism and ammonia production during exercise. In: Hargreaves $M$ (ed) Exercise metabolism. Human Kinetics, Champaign IL, pp 131-175

13. Greenhaff PL, Clough PJ (1989) Predictors of sweat loss in man during prolonged exercise. Eur J Appl Physiol $58: 348-352$

14. Heyningen R, Weiner IS (1952) A comparison of arm-bag sweat and body sweat. J Physiol 116:395-403

15. Itoh $S$, Nakayama $T$ (1952) Amino acids in human sweat. Japan J Physiol $2: 248-253$
16. Lemon PWR, Mullin JP (1980) Effect of initial muscle glycogen levels on protein catabolism during exercise. $\mathbf{J}$ Appl Physiol 48:624-629

17. Lemon PWR, Yarasheski KE, Dolny G (1986) Validity/reliability of sweat analysis by whole-body washdown vs. regional collections. J Appl Physiol 61:1967-1971

18. Lemon PWR (1983) A simple and inexpensive method for making sweat collection capsules. Res Q Exerc Sport 54:299-301

19. Lemon PWR (1997) Dietary protein requirements in athletes. $J$ Nutr Biochem $8: 52-60$
20. Liappis N, Kelderbacher SD, Kesseler K, Bantzer P (1979) Quantitative study of free amino acids in human accrine sweat excreted from the forearms of healthy trained and untrained men during exercise. Eur J Appl Physiol 42:227-234

21. Simon G, Berg A, Dickhuth H-H, Simon-Alt A, Keul J (1981) Bestimmung der anaeroben Schwelle in Abhängigkeit vom Alter und der Leistungsfähigkeit. Dtsch Z Sportmed 32:7-14

22. US Food \& Nutrition Board (1989) Recommended Dietary Allowances $10^{\text {th }}$ edition. National Academy Press, Washington DC, p 66 